\title{
Keratin 17 Immunohisto chemical Expression and Prognostic Value in Bladder Urothelial Carcinoma
}

\author{
SHAIMAA M.M. BEBARS, M.D.*; WALAA ABD EL GAWAD GHANAM, M.D.** and \\ RASHA MOHAMED SAMIR SAID, M.D.* \\ The Department of Pathology, Faculty of Medicine, Aswan* and Suez** Universities, Egypt
}

\begin{abstract}
Background: Bladder cancer is the 2 nd most common site of cancer in Egyptian males (12.7\%), compared to other countries, the incidence and mortality rates are high. The ratio of Squamous Cell Carcinoma (SCC) \& Urothelial Carcinoma (UC) types showed a shift towards UC. Keratin 17 (K17) is an oncoprotein that has a role in tumor progression. $\mathrm{K} 17$ is overexpressed in SCC, triple negative breast cancer \& others.

Aim of Study: This study aimed to explore the expression of $\mathrm{K} 17$ protein in UC in bladder biopsies of Egyptian cases. Also, to correlate K17 expression with the available clinicopathological data of the studied cases.

Patients and Methods: This study was carried out on 60 cases of Egyptian bladder UC. Sections of the collected paraffin blocks were performed and applied for Immunohistochemical staining with K17, mouse monoclonal anti-human K17 antibody. Positive K17 cases assessed for intensity staining and distribution of positive stained cells into (mild, moderate and strong) staining results.
\end{abstract}

Results: K17 showed high expression in UC Egyptian patients biopsies $(56.7 \%)$, strong intensity was found in more than half of positive cases while it was negative in normal urothelium. K17 is more expressed in papillary UC pattern and more related to bad prognosis features as high grade and muscle invasion. Significant association was detected between positive K17 and squamous differentiation in UC cases. All moderate intensity $(100 \%)$ and majority of strong staining $(77.8 \%)$ were of papillary UC $(p<0.001)$. In addition, significant association was found between moderate \& strong K17 intensity and negative schistosomiasis ovae cases $(p=0.003)$

Conclusion: Our study calls for considering high expression of K17 in UC especially papillary pattern, high grade \& muscle invasion. This study also sheds light on significant association of $\mathrm{K} 17$ in UC with squamous differentiation \& absence of Schistosomiasis.

Key Words: Urothelial carcinoma - K17 - Immunohistochemistry-Biomarker.

Correspondence to: Dr. Shaimaa M.M. Bebars, The Department of Pathology, Faculty of Medicine, Aswan University, Aswan, Egypt

\section{Introduction}

BLADDER cancer is a concern worldwide; most recent report shows that it represents the 10 th most common diagnosed cancer $\&$ number of new cases is 549,393 (3\%) according to Bray et al., 2018 [8] It is the 6 th common cancer in men and represents much lower incidence in women (17 th ) [8,9]. The highest incidence of bladder cancer is detected in Southern and Western Europe [2,8]. Age standardized risk in male is $9.6 \&$ in female 2.4 [8]. Bladder Cancer incidence is related to geographical distribution, with the highest age-standardized incidence rate per 100,000 people to be found in Belgium (17.5 cases) [29], it is also dominant in Lebanon (16.6 cases) [43]. Bladder cancer is more frequent in American than in Asian countries [12]. In America, bladder cancer represents only $7 \%$ of all cancers in men [32]

Regarding mortality, it represents 13 th most frequent cause of death [2]. Number of death cases represents $2.1 \%$ according to Bray et al., 2018 [8] The observed highest standardized mortality rates were found in Turkey \& Egypt [2,10]. Bladder cancer standardized mortality rate/100,000 per year is different between men and women ranging from 2-10 \& 0.5-4 (respectively) [37]. In men, the highest mortality rates were observed in Western Asia \& Northern Africa [48].

Bladder cancer higher incidence in male than in female may be related to differences in risk factors exposure [22]. Variation in the incidence rates of bladder cancer according to geographical changes points to the influence of various factors [23]. The studied factors as a major risk were: Tobacco smoking as a most common factor in western countries [35] ; family history of bladder cancers as the risk is twice as high in first degree relatives 
[9], this may be related to tobacco exposure in same family or could be hereditary genetic changes that make it difficult to decompose some of the toxins in the body causing bladder cancer $[\mathbf{3 1}, \mathbf{4 6}]$. Industrial work exposure to potential carcinogens e.g. aromatic amines \& carbon black dust, prolonged drinking of arsenic-contaminated or chlorinated water are other risk factors $[\mathbf{9 , 1 5}]$. In addition, chronic urinary tract infection with Schistosoma hematobium (S. Hematobium) is a major risk in certain countries [2] . It is proposed that, Geneenvironment interactions may play a major role as a risk factor especially for tobacco and occupational exposures [14]

Bladder cancer is the 2 nd most common site of cancer in Egyptian males (12.7\%). According to lower Egypt 2009-2011 reports, it represents 8.82\% and $2.77 \%$ of cancer incidence rate in male and female respectively. Compared to other countries, the incidence and mortality rates are high in Egypt, the incidence represents $16.2 \%$ of all cancers, the age-standardized incidence rate is $21.1 / 100,000 \&$ standardized mortality rate is $6.5 / 100,000$ people $[10,20,23,27,32]$.

There are two main histological types of urinary bladder cancer, Urothelial Carcinoma (UC) and Squamous Cell Carcinoma (SCC). In Western Europe and USA, the majority (90\%) of bladder cancer consists of UC. In Africa, SCC of bladder was more common [16,41]. In Egypt, the ratio of SCC and UC types showed a shift towards UC, with SCC decreasing and UC increasing, as reports show that only $27-30 \%$ of the cases are of SCC type $[1,24,34]$

In Egypt, South residency, age, sex, late year of diagnosis, and $\mathrm{S}$. hematobium infection were all significantly associated with the UC type in the univariate analyses done by Felix and colleagues in 2008. 82\% of all bladder cancer Egyptian patients are carriers of S. hematobium eggs. This represents the main risk factor of bladder cancer and is more frequent in Upper Egypt. It has been proposed that young people with positive eggs in their bladders has a greater tendency to spread the tumor $[6,19]$ It should be considered that $\mathrm{S}$. hematobium infection was detected in bladder cancer cases, both UC \& SCC [34]

According to Amin, 2013 major risk factors in Upper Egypt include positive family history, exposure to pesticides, bladder stones apart from schistosomiasis. Another studied factor was loss of the $\mathrm{Y}$ chromosome by Fluorescence in Situ Hybridization (FISH) technique. This was detected in 7 of the $17(41 \%)$ Schistosomiasis-associated bladder cancer Egyptian cases reported by Khaled and his colleagues [30]

Sometimes the diagnosis and confirmation of bladder cancer becomes a challenge. There is always a need for new biomarkers to be used for detection, diagnosis and prognosis of bladder cancer $[4,7]$.

$\mathrm{K} 17$ is a type of keratin (epithelial predominant intermediate filament) [13]. The role of K17 in tumor progression was proved by Grachtchouk et al., [24]. K17 functions as an oncoprotein that promotes p27KIP1 nuclear export and degradation [18]. K17 is overexpressed in SCC [40]. EscobarHoyos and co-workers in 2014 [18], reported that K17 could predict the overall survival of patients with cervical SCC. However, in triple-negative breast carcinoma, gastric adenocarcinoma, epithelial ovarian carcinoma \& oropharyngeal SCC, K17 is a negative prognostic indicator $[\mathbf{2 8 , 4 2 , 4 5 , 4 7 ]}$. In addition, it is proposed that $\mathrm{K} 17$ is highly expressed not only in cervical SCC, but also in most cases of both insitu \& invasive cervical adenocarcinomas. It is also considered as a negative prognostic marker in these cases [38].

He et al., 2009 studied tumorigenic basal cell compartment in UC \& showed that K17 mark a basal-like population. To our knowledge only Babu and his colleagues in 2019 [4] studied K17 expression by immunohistochemistry in formalin-fixed, paraffin embedded tissue specimens of UC.

The current study aimed to investigate keratin 17 (K17), as a diagnostic biomarker of UC in bladder biopsies of Egyptian cases and to correlate its expression with the available clinicopathological data of the studied cases.

\section{Patients and Methods}

This study was carried out on 60 cases of Egyptian bladder UC. These cases were selected from archives of Pathology Department, Faculty of Medicine Aswan University and private laboratories. Cases were collected as paraffin embedded blocks of all TURT specimens (Transurethral resection of bladder tumor). Eighteen cases [18] cases of normal urinary bladder tissue fragments were also used as a control cases for comparison.

The selected formalin fixed, paraffin-embedded tissue blocks are sectioned and stained with $\mathrm{H} \&$ $\mathrm{E}$ for routine histopathologic examination.

Histopathological evaluation was performed by two pathologists to classify the cases into (urothelial carcinoma and papillary urothelial car- 
cinoma) according to architecture of papillae formation. Grading of the cases according to (World Health Organization/International Society of Urologic Pathologists consensus classification-WHO ISUP 2016), into low grade and high grade cases according to polarity of tumor cells and cytological atypia. Also assessment of lamina propria invasion and muscularis propria invasion was done. All cases were negative for vascular invasion by tumor cells. Assessment of presence of calcified Bilharzial ova or not was done.

Sections of the collected paraffin blocks were performed and applied for automated autostainer for K17, mouse monoclonal anti-human K17 antibody. Positive control is normal skin tissue, as it is basal cytokeratin for basal cells layer and interprented as cytoplasmic staining.

Cases were examined after staining with K17 and evaluated for positive or negative staining results through the whole thickness of tumor tissue. Positive K17 cases assessed for intensity staining and distribution of positive stained cells into (mild, moderate and strong) staining results and compared with findings reported in literature and the control cases.

\section{Statistical analysis of the data:}

Data were fed to the computer and analyzed using IBM SPSS software package version 20.0. (Armonk, NY: IBM Corp) qualitative data were described using number and percent. The Kolmogorov-Smirnov test was used to verify the normality of distribution quantitative data were described using range (minimum and maximum), mean, standard deviation and median. Significance of the obtained results was judged at the $5 \%$ level (Kotz et al. 2006, and Kirkpatrick et al., 2013).

\section{The used tests were:}

1- Chi-square test: For categorical variables, to compare between different groups.

2- Monte Carlo correction: Correction for chisquare when more than $20 \%$ of the cells have expected count less than 5 .

Differences were considered as follows: (Dawson and Trapp 2001):

- Statistically significant (S) when $(p<0.05)$.

- Highly significant (HS) when $(p<0.01)$.

- Not significant (NS) when ( $p>0.05)$.

\section{Results}

Out of total 60 patients included in the study, $76.7 \%$ were men, the majority (two third) of pa- tients were older than 60 years with median age 65. More than three fourth of the cases were diagnosed as papillary UC. Only $23.3 \%$ of all cases were noninvasive, $47.8 \%$ showed muscle invasion. Of all UC cases $76.6 \%$ were of high grade. Squamous differentiation was detected in 34/60 cases. Schistosomiasis ovae were found in $23.3 \%$ of all cases (Table 1).

More than three fourth of UC studied cases showed lamina propria invasion. Out of 46 positive lamina propria invasion cases, 22 cases showed muscle invasion (47.8\%) (Table 1) \& Fig. (1).

K17 was negative in all normal urothelial tissue cases (18). Out of 60 cases of UC, 34 were stained positive for K17 representing (56.7\%). Strong intensity was detected in more than half of positive cases $(18 / 34)$ (Table 1).

Table (1): Distribution of the studied cases according to different parameter $(n=60)$.

\begin{tabular}{|c|c|}
\hline & No. (\%) \\
\hline $\begin{array}{l}\text { Sex: } \\
\quad \text { Male } \\
\text { Female }\end{array}$ & $\begin{array}{l}46(76.7 \%) \\
14(23.3 \%)\end{array}$ \\
\hline $\begin{array}{l}\text { Age (years): } \\
\quad \leq 60 \\
>60 \\
\text { Median (min.-max.) } \\
\text { Mean } \pm \text { SD }\end{array}$ & $\begin{array}{l}20(33.3) \\
40(66.7) \\
65(47-80) \\
63.1 \pm 9.9\end{array}$ \\
\hline $\begin{array}{l}\text { Histopathological diagnosis: } \\
\text { Papillary urothelial carcinoma } \\
\text { Urothelial carcinoma }\end{array}$ & $\begin{array}{l}46(76.7 \%) \\
14(23.3 \%)\end{array}$ \\
\hline $\begin{array}{c}\text { Grade: } \\
\text { Low } \\
\text { High }\end{array}$ & $\begin{array}{l}14(23.3 \%) \\
46(76.7 \%)\end{array}$ \\
\hline $\begin{array}{l}\text { Squamous differentiation: } \\
\text { Negative } \\
\text { Positive }\end{array}$ & $\begin{array}{l}26(43.3 \%) \\
34(56.7 \%)\end{array}$ \\
\hline $\begin{array}{l}\text { Lamina propria invasion: } \\
\text { Negative } \\
\text { Positive } \\
\text { Negative Muscle invasion } \\
\text { Positive Muscle invasion }\end{array}$ & $\begin{array}{l}14(23.3 \%) \\
46(76.7 \%) \\
24(52.2 \%) \\
22(47.8 \%)\end{array}$ \\
\hline $\begin{array}{l}\text { Urothelial carcinoma K17: } \\
\text { Negative } \\
\text { Positive }\end{array}$ & $\begin{array}{l}26(43.3 \%) \\
34(56.7 \%)\end{array}$ \\
\hline $\begin{array}{l}\text { Intensity of K17 staining: } \\
\text { Negative } \\
\text { Mild } \\
\text { Moderate } \\
\text { Strong }\end{array}$ & $\begin{array}{l}26(43.3 \%) \\
4 \quad(6.7 \%) \\
12(20 \%) \\
18(30 \%)\end{array}$ \\
\hline $\begin{array}{l}\text { Bilharzial ova infection: } \\
\text { Negative } \\
\text { Positive }\end{array}$ & $\begin{array}{c}46(76.7 \%) \\
14(23.3 \%)\end{array}$ \\
\hline
\end{tabular}




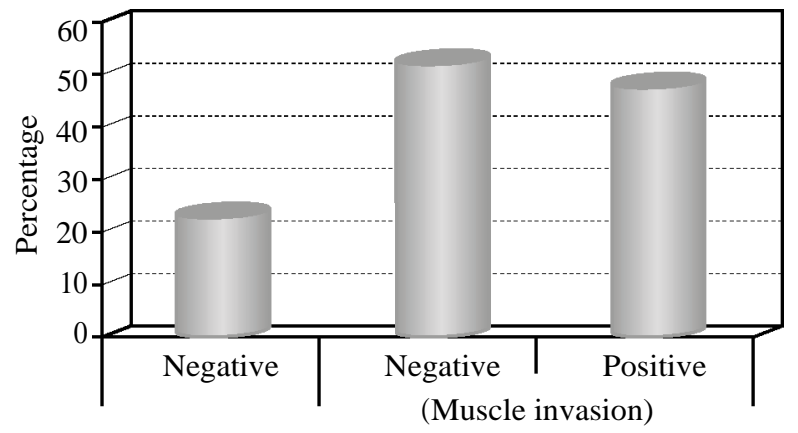

Lamina propria invasion

Fig. (1): Distribution of the studied cases according to lamina propria invasion $(n=60)$
Although no significant difference could be detected when comparing K17 positive and negative cases in male and female UC patients. $76.5 \%$ of positive cases were older than $60 \mathrm{y}$. More than $3 / 4$ of the positive k17 cases were papillary UC Fig. (2). High grade UC showed more positive k17 than low grade (26 versus 8) Fig. (3), (Table 2).

Significant difference was found when comparing frequency of K17 in cases with squamous differentiation \& with no squamous differentiation Fig. (4) \& (Table 2).

Table (2): Relation between urothelial carcinoma kertien 17 and different parameters $(n=60)$.

\begin{tabular}{|c|c|c|c|c|}
\hline & \multicolumn{2}{|c|}{ Urothelial carcinoma (Keratin 17) } & \multirow{2}{*}{$\begin{array}{l}\text { Test } \\
\text { of sig. }\end{array}$} & \multirow[b]{2}{*}{$p$} \\
\hline & $\begin{array}{l}\text { Negative } \\
(n=26)\end{array}$ & $\begin{array}{c}\text { Positive } \\
(\mathrm{n}=34)\end{array}$ & & \\
\hline \multicolumn{5}{|l|}{ Sex: } \\
\hline Male & $22(84.6 \%)$ & $24(70.6 \%)$ & $\chi^{2}=$ & 0.203 \\
\hline Female & $4 \quad(15.4 \%)$ & $10(29.4 \%)$ & 1.621 & \\
\hline \multicolumn{5}{|l|}{ Age (years): } \\
\hline$\leq 60$ & $12(46.2 \%)$ & $8 \quad(23.5 \%)$ & $\chi=$ & 0.065 \\
\hline$>60$ & $14(53.8 \%)$ & $26(76.5 \%)$ & 3.394 & \\
\hline Median (min.-max.) & $62(48-80)$ & $67(47-80)$ & & 0.112 \\
\hline Mean $\pm S D$ & $60.8 \pm 9.3$ & $64.9 \pm 10.1$ & 1.615 & \\
\hline \multicolumn{5}{|l|}{ Histopathological diagnosis: } \\
\hline Papillary urothelial carcinoma & $20(76.9 \%)$ & $26(76.5 \%)$ & $\chi^{2}=$ & 0.967 \\
\hline Urothelial carcinoma & $6 \quad(23.1 \%)$ & $8 \quad(23.5 \%)$ & 0.002 & \\
\hline \multicolumn{5}{|l|}{ Grade: } \\
\hline Low & $6 \quad(23.1 \%)$ & $8 \quad(23.5 \%)$ & $\chi=$ & 0.967 \\
\hline High & $20(76.9 \%)$ & $26(76.5 \%)$ & 0.002 & \\
\hline \multicolumn{5}{|l|}{ Squamous differentiation: } \\
\hline Negative & $18(69.2 \%)$ & $8 \quad(23.5 \%)$ & $\chi^{2}=$ & $<0.001 *$ \\
\hline Positive & $8 \quad(30.8 \%)$ & $26(76.5 \%)$ & $12.532 *$ & \\
\hline \multicolumn{5}{|l|}{ Lamina propria invasion: } \\
\hline Negative & $4 \quad(15.4 \%)$ & $10(29.4 \%)$ & $\chi^{2}=$ & 0.203 \\
\hline Positive & $22(84.6 \%)$ & $24(70.6 \%)$ & 1,621 & \\
\hline Negative Muscle invasion & $14(63.6 \%)$ & $10(41.7 \%)$ & $\chi^{2}=$ & 0.136 \\
\hline Positive Muscle invasion & $8 \quad(36.4 \%)$ & $14(58.3 \%)$ & 2.220 & \\
\hline
\end{tabular}

$\chi^{2}:$ Chi square test. $\quad t$ : Student $t$-test.

$p: p$-value for association between urotheial carcinoma kertien 17 and different parameters

$*$ : Statistically significant at $p \leq 0.05$.

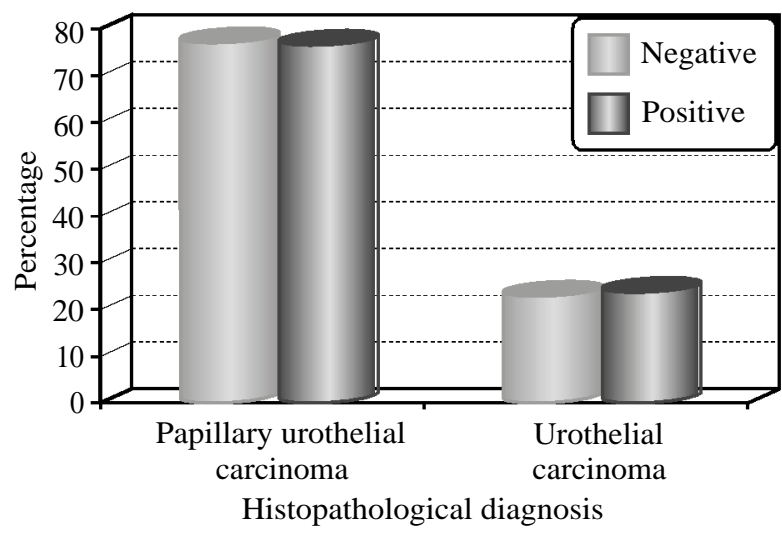

Fig. (2): Relation between urothelial carcinoma kertien 17 and histopathological diagnosis $(n=60)$.

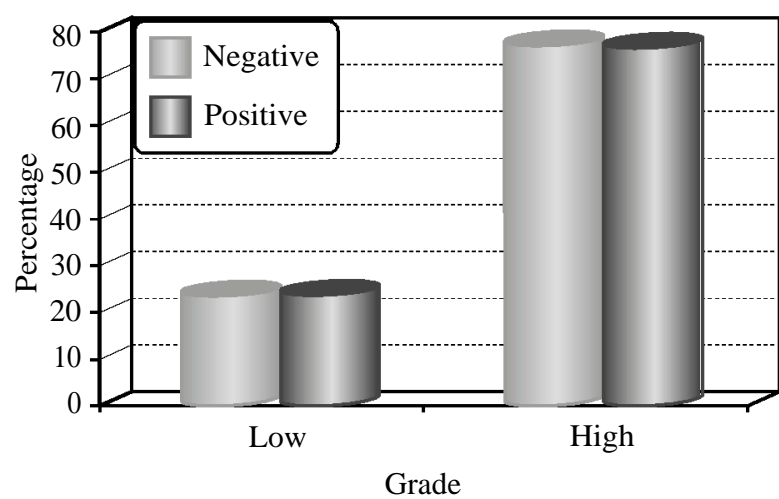

Fig. (3): Relation between urothelial carcinoma kertien17 and grade $(n=60)$. 


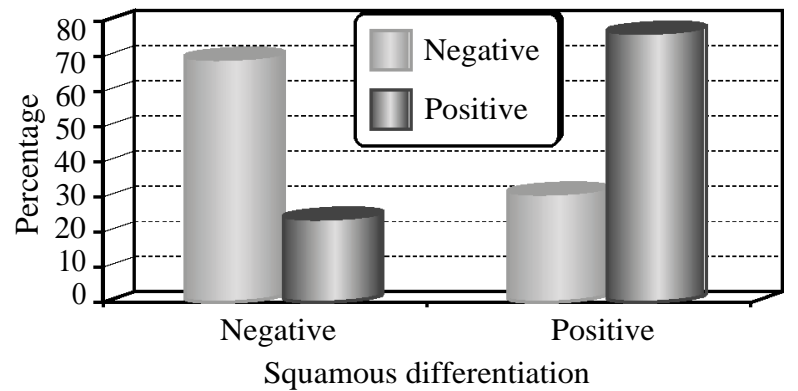

Fig. (4): Relation between urothelial carcinoma kertien 17 and squamous differentiation $(n=60)$.
When comparing different staining of $\mathrm{k} 17$ intensity there is a significant difference between papillary and non-papillary UC cases. All moderate intensity $(100 \%)$ and majority of strong staining $(77.8 \%)$ were of papillary UC ( $p<$ $0.001)$. Significant association was found between moderate \& strong K17 intensity and negative schistosomiasis ovae $(p=0.003)$. (Table $3)$, Figs. $(5,6)$.

Table (3): Relation between Intensity of Keratin 17 staining and different parameters $(n=34)$.

\begin{tabular}{|c|c|c|c|c|c|}
\hline & \multicolumn{3}{|c|}{ Intensity of Keratin 17 staining } & \multirow{2}{*}{$x^{2}$} & \multirow[b]{2}{*}{$p$} \\
\hline & $\begin{array}{l}\text { Mild } \\
(\mathrm{n}=4)\end{array}$ & $\begin{array}{c}\text { Moderate } \\
(\mathrm{n}=12)\end{array}$ & $\begin{array}{l}\text { Strong } \\
(\mathrm{n}=18)\end{array}$ & & \\
\hline \multicolumn{6}{|l|}{ Histopathological diagnosis: } \\
\hline Papillary urothelial carcinoma & $0(0 \%)$ & $12(100 \%)$ & $14(77.8 \%)$ & $13.896^{*}$ & $<0.001 *$ \\
\hline Urothelial carcinoma & $4(100 \%)$ & $0(0 \%)$ & $4 \quad(22.2 \%)$ & & \\
\hline \multicolumn{6}{|l|}{ Grade: } \\
\hline Low & $0(0 \%)$ & $4(33.3 \%)$ & $4 \quad(22.2 \%)$ & 1.487 & 0.535 \\
\hline High & $4(100 \%)$ & $8(66.7 \%)$ & $14(77.8 \%)$ & & \\
\hline \multicolumn{6}{|l|}{ Squamous differentiation: } \\
\hline Negative & $0(0 \%)$ & $4(33.3 \%)$ & $4 \quad(22.2 \%)$ & 1.487 & 0.535 \\
\hline Positive & $4(100 \%)$ & $8(66.7 \%)$ & $14(77.8 \%)$ & & \\
\hline \multicolumn{6}{|l|}{ Lamina propria invasion: } \\
\hline Negative & $0(0 \%)$ & $4(33.3 \%)$ & $6 \quad(33.3 \%)$ & 1.549 & 0.586 \\
\hline Positive & $4(100 \%)$ & $8(66.7 \%)$ & $12(66.7 \%)$ & & \\
\hline Negative Muscle invasion & $0(0 \%)$ & $4(50 \%)$ & $6(50 \%)$ & 3.204 & 0.225 \\
\hline Positive Muscle invasion & $4(100 \%)$ & $4(50 \%)$ & $6 \quad(50 \%)$ & & \\
\hline \multicolumn{6}{|l|}{ Bilharzial ova infection: } \\
\hline Negative & $0(0 \%)$ & $8(66.7 \%)$ & $16(88.9 \%)$ & $11.147 *$ & $0.003^{*}$ \\
\hline Positive & $4(100 \%)$ & $4(33.3 \%)$ & $2(11.1 \%)$ & & \\
\hline
\end{tabular}

$\mathrm{X}^{2}$ : Chi square test.

$p: p$-value for association between intensity of Keratin 17 staining and different parameters.

*: Statistically significant at $p \leq 0.05$.

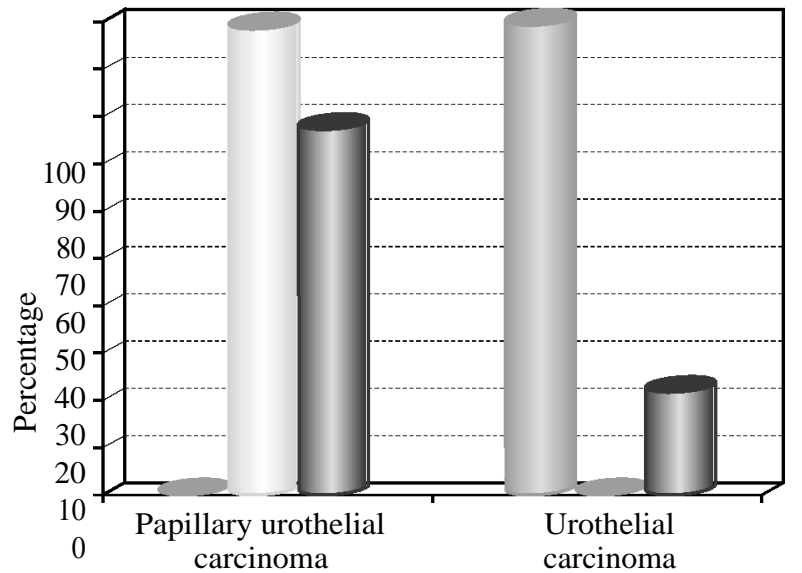

Histopathological diagnosis

Mild $\mid$ Moderate

Fig. (5): Relation between intensity of Keratin 17 staining and histopathological diagnosis $(\mathrm{n}=34)$.

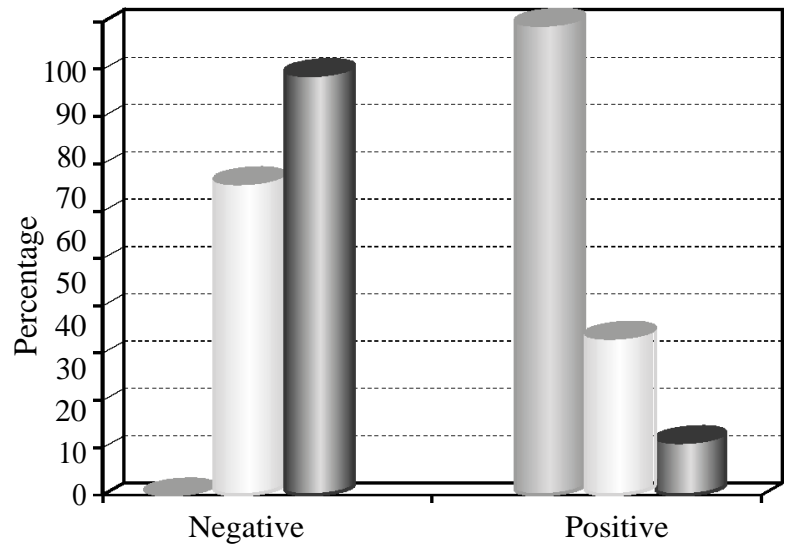

Bilharzial ova infection

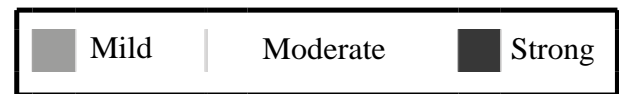

Fig. (6): Relation between intensity of Keratin 17 staining and Bilharzial ova infection $(n=34)$. 

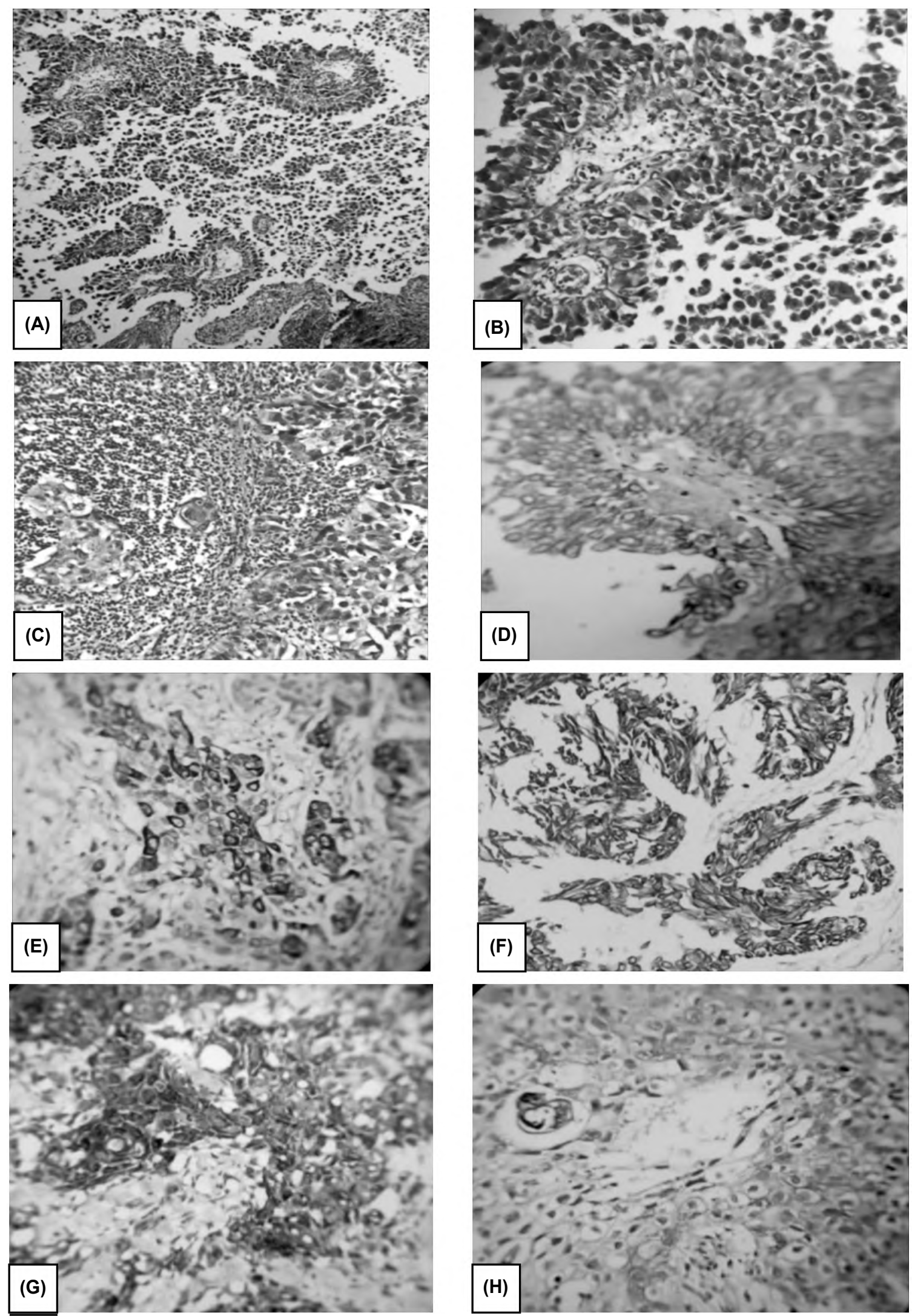

Fig. (7): (A): H \& E (100x) of papillary UC (low grade). (B): H \& E (400x) of papillary UC (high grade). (C): H \& E (400x) of UC (high grade). (D): K17 expression, moderate staining of whole thickness of papillary UC (low grade) (200x). (E): K17 expression, strong staining results of UC (high grade) (400x). (F): K17 expression, strong staining results of whole thickness of UC (high grade) (400x). (G): K17 expression, strong staining results of whole thickness of UC (high grade) (400x). (H): K17 expression, mild to moderate staining results of area with squamous differentiation \& adjacent Bilharzial ova. 


\section{Discussion}

In Egyptian patients, bladder carcinoma shows high incidence in male and is an important cause of death especially in Upper Egypt. In this study, we investigate $\mathrm{K} 17$ immunohistochemistry expression in 60 bladder UC biopsies of Egyptian patients. 18 normal bladder tissues were added as a control.

Out of total 60 patients included in the study, (76.6\%) were men, this was expected as all reports worldwide and from Egypt show male predominance $[\mathbf{1 , 2 , 8 , 2 1 ]}$. The majority (two third) of patients were older than 60 years with median age 65 and mean age $63.1 \pm 9.9$. This old age of presentation goes in concordance with other studies, where UC is usually more frequent in older age than SCC $[17,25,49]$. UC mean age of 61 years was identified in the studies of; Amin, 2013 [1] who reported bladder cancer from Assuit in Egypt, also, Asar and coworkers [3] research from National Cancer Institute in Egypt, and Kyritsi et al., [34] in his recent research of urinary bladder cancer in Egypt. Mohamed et al., [39] from Zagazig studied cases in Egypt reported 64 as main age of UC. Felix and colleagues in 2008 [21] attributed late presentation of UC in Egypt to long incubation period in exposure to smoking and carcinogens.

In the current study, more than three fourth of the cases were diagnosed as papillary UC. This is similar to findings of Koyuncuer, 2015 [33] of Transurethral Resection urinary bladder tumor specimens. A papillary tumor pattern was detected in $67.2 \%$ of their UC studied cases.

Only $23.3 \%$ of all cases were noninvasive, this goes with report of Asar and coworkers, 2017 [3] of noninvasive UC cases to represent $29.7 \%$. In this work, more than three fourth of UC studied cases showed lamina propria invasion and near half of cases $(47.8 \%)$ showed muscle invasion. This is close to results of Asar et al., 2017 and Kyritsi et al., 2018 [13,34] who found that the majority of UC cases were invasive and reported that muscle invasion was noted in $\sim 55 \& 59 \%$ respectively.

Of all UC studied cases, majority of cases $(76.6 \%)$ were of high grade, this is similar to the study of Amin, 2013 [1] who reported that majority of included UC cases were high grade $(62.7 \%)$. Also, Asar et al., 2017 [3] reported high grade UC as $85.7 \%$ of their studied cases.

Squamous differentiation was detected in more than half of cases (34/60), this presentation in $(57.7 \%)$ of cases is similar to Black et al., 2009
[5] who reported squamous differentiation in $60 \%$ of cases. On the other hand, Amin, 2013 [1] record of squamous cell differentiation in only $6.2 \%$. While, Liu et al., 2017 [36] detected it in $19.3 \%$ of radical cystectomy cases for UC in Roswell Park Cancer Institute. This variation can be related to indefinite criteria for squamous differentiation in UC and different geographical distribution with variable factors affecting metaplasia, also cystectomy specimen could vary from biopsy.

Schistosomiasis ovae were found in $23.3 \%$ of all cases. This is close to the report of Amin, 2013 [1], that $27.8 \%$ of her patients have history of Schistosomiasis. While, Kyritsi et al., 2018 [34] reported that schistosomiasis ovae were found in $59 \%$ of male and $42 \%$ of female UC Egyptian patients. Their higher percentage may be due to larger scale of cases as they conducted it as a multicenter casecontrol study between 2006 and 2014. The detection of Schistosomiasis is of relative low incidence in UC than SCC especially nowadays due to prolonged efforts to eradicate such a disease from Egypt [49]

In the current work, K17 was negative in all normal urothelial tissue cases [18]. This is because $\mathrm{K} 17$ is not found in most of adult tissue but only in some stem cells [11]. According to Babu et al., 2019 [4] report, normal urothelial epithelium rarely stains for K17.

Out of 60 cases of UC, 34 were stained positive for K17 representing (56.7\%). In addition, strong intensity was detected in more than half of positive cases (18/34). This indicates high frequency of $\mathrm{K} 17$ in UC especially strong intensity. This supports the conclusion of Babu et al., 2019 [4] that K17 can help as a sensitive and specific diagnostic biomarker in UC.

In this study, no significant difference could be detected when comparing K17 positive and negative cases in male and female UC patients. $76.5 \%$ of positive cases were older than 60 years. More than 3/4 of the positive K17 cases were papillary UC. High grade UC showed more frequent K17 positivity than low grade (26 versus 8 ). Cases of muscle invasion showed more frequent expression of K17 than cases of non-muscle invasion and this is supported by record of Babu et al., 2019 [4] They showed significant higher proportion of K17 positive tumor cells in muscle invasion cases. Although no significant association could be detected, these data indicate that K17 is more expressed not only in cases with papillary pattern but also in relation to bad prognosis features as high grade and muscle invasion. 
Significant difference was found when comparing frequency of K17 in cases with squamous differentiation \& with no squamous differentiation. (76.5\%) of positive K17 showed squamous differentiation. Somji et al., 2011 [44] who studied a transformed urothelial cancer cell line, demonstrated that foci of squamous differentiation of urothelial tumor cells express K17.

When comparing different staining intensity of $\mathrm{K} 17$ there is a significant difference between papillary and non-papillary UC cases. All moderate intensity $(100 \%)$ and majority of strong staining (77.8\%) were of papillary UC $(p<0.001)$. However, this is not the case in the study of Babu et al., 2018 [4] who reported that non papillary UC showed greater proportion of K17 positivity. This difference can be explained by different categorization, as they reported papillary urothelial neoplasia of low malignant potential PUNLMP, low-grade papillary together and high grade papillary (noninvasive and invasive) cases as papillary UC cases while in this study we did not include PUNLUMP, we separated papillary and nonpapillary cases apart from invasive and noninvasive, high or low grade.

We detected significant association between moderate \& strong K17 intensity and negative Schistosomiasis ovae cases ( $p=0.003)$. This means $\mathrm{K} 17$ is mainly not related to Schistosomiasis.

In conclusion, K17 showed high expression in UC Egyptian patients biopsies (56.7\%), strong intensity was found in more than half of positive cases while it was negative in normal urothelium. $\mathrm{K} 17$ is more expressed in papillary UC pattern and more related to bad prognosis features as high grade and muscle invasion. Significant association was detected between positive K17 and squamous differentiation in UC cases. All moderate intensity $(100 \%)$ and majority of strong staining $(77.8 \%)$ were of papillary UC $(p<0.001)$. In addition, significant association was found between moderate \& strong K17 intensity and negative schistosomiasis ovae cases ( $p=0.003)$. This shed light on expression of K17 in relation to UC especially papillary pattern, squamous differentiation and in absence of Schistosomiasis.

\section{References}

1- AMIN A.F.: Epidemiological study of bladder cancer and risk factors in Upper Egypt. A.A.M.J., 11 (2), 2013.

2- ANTONI S., FERLAY J., SOERJOMATARAM I., ZNAOR A., JEMAL A. and BRAY F.: Bladder cancer incidence and mortality: A global overview and recent trends. European Urology, 71 (1): pp. 96-108, 2017.
3- ASAR A., GABAL S., HELMY N. and KHALIFA S.E. Immunohistochemical study of the expression of Oct.-4 in bladder urothelial carcinoma. Kasr Al-Ainy Medical Journal, 23 (3), p. 141, 2017.

4- BABU S., MOCKLER D.C., ROA-PEÑA L., SZYGALOWICZ A., KIM N.W., JAHANFARD S., GHOLAMI S.S., MOFFITT R., FITZGERALD J.P., ESCOBARHOYOS L.F. and SHROYER K.R.: Keratin 17 is a sensitive and specific biomarker of urothelial neoplasia. Modern Pathology, 32 (5): p. 717, 2019.

5- BLACK P.C., BROWN G.A. and DINNEY C.P.: January. The impact of variant histology on the outcome of bladder cancer treated with curative intent. In Urologic Oncology: Seminars and Original Investigations (Vol. 27, No. 1, pp. 3-7). Elsevier, 2009.

6- BOTELHO M., FERREIRA A.C., OLIVEIRA M.J., DOMINGUES A., MACHADO J.C. and Da COSTA J.M.C.: Schistosoma haematobium total antigen induces increased proliferation, migration and invasion, and decreases apoptosis of normal epithelial cells. International Journal for Parasitology, 39 (10): pp. 1083-91, 2009.

7- BOTTEMAN M.F., PASHOS C.L., REDAELLI A., LASKIN B. and HAUSER R.: The health economics of bladder cancer. Pharmacoeconomics, 21 (18): pp. 131530, 2003.

8- BRAY F., FERLAY J., SOERJOMATARAM I., SIEGEL R.L., TORRE L.A. and JEMAL A.: Global cancer statistics 2018: GLOBOCAN estimates of incidence and mortality worldwide for 36 cancers in 185 countries. CA: A Cancer Journal for Clinicians, 68 (6): pp. 394-424, 2018.

9- BURGER M., CATTO J.W., DALBAGNI G., GROSSMAN H.B., HERR H., KARAKIEWICZ P., KASSOUF W., KIEMENEY L.A., La VECCHIA C., SHARIAT S. and LOTAN Y.: Epidemiology and risk factors of urothelial bladder cancer. European Urology, 63 (2): pp. 234-41, 2013.

10- CHAVAN S., BRAY F., LORTET-TIEULENT J., GOODMAN M. and JEMAL A.: International variations in bladder cancer incidence and mortality. European Urology, 66 (1): pp. 59-73, 2014.

11- CHU P.G. and WEISS L.M.: Keratin expression in human tissues and neoplasms. Histopathology, 40: pp. 403-39, 2002.

12- COLOMBEL M., SOLOWAY M., AKAZA H., BÖHLE A., PALOU J., BUCKLEY R., LAMM D., BRAUSI M., WITJES J.A. and PERSAD R.: Epidemiology, staging, grading, and risk stratification of bladder cancer. European Urology Supplements, 7 (10): pp. 618-26, 2008.

13- COULOMBE P.A. and OMARY M.B.: 'Hard'and 'soft' principles defining the structure, function and regulation of keratin intermediate filaments. Current opinion in cell biology, 14 (1): pp. 110-22, 2002.

14- CUMBERBATCH M.G.K., JUBBER I., BLACK P.C., ESPERTO F., FIGUEROA J.D., KAMAT A.M., KIEMENEY L., LOTAN Y., PANG K., SILVERMAN D.T. and ZNAOR A.: Epidemiology of bladder cancer: A systematic review and contemporary update of risk factors in 2018. European Urology, 74 (6): pp. 784-95, 2018.

15- DANESHMAND S.: Epidemiology and risk factors of urothelial (transitional cell) carcinoma of the bladder. 
UpToDate http://www. uptodate. com/contents/ epidemiolo gy-and-risk-factors-of-urothelial-transitional-cellcarcinoma-of-the-bladder (Date of access: 06/07/2017), 2016.

16- EL MAWLA N.G., EL BOLKAINY M.N. and KHALED H.M.: April. Bladder cancer in Africa: Update. In Seminars in oncology (Vol. 28, No. 2, pp. 174-8). WB Saunders, 2001.

17- EL-SEBAIE M., ZAGHLOUL M.S., HOWARD G. and MOKHTAR A.: Squamous cell carcinoma of the bilharzial and non-bilharzial urinary bladder: A review of etiological features, natural history, and management. International Journal of Clinical Oncology, 10 (1): pp. 20-5, 2005.

18- ESCOBAR-HOYOS L.F., YANG J., ZHU J., CAVALLO J.A., ZHAI H., BURKE S., KOLLER A., CHEN E.I. and SHROYER K.R.: Keratin 17 in premalignant and malignant squamous lesions of the cervix: Proteomic discovery and immunohistochemical validation as a diagnostic and prognostic biomarker. Modern Pathology, 27 (4): p. 621, 2014.

19- EZZAT S., ABDEL-HAMID M., EISSA S.A.L., MOKHTAR N., LABIB N.A., EL-GHORORY L., MIKHAIL N.N., ABDEL-HAMID A., HIFNAWY T., STRICKLAND G.T. and LOFFREDO C.A.: Associations of pesticides, HCV, HBV, and hepatocellular carcinoma in Egypt. International Journal of Hygiene and Environmental Health, 208 (5): pp. 329-39, 2005.

20- FEDEWA S.A., SOLIMAN A.S., ISMAIL K., HABLAS A., SEIFELDIN I.A., RAMADAN M., OMAR H.G., NRIAGU J. and WILSON M.L.: Incidence analyses of bladder cancer in the Nile delta region of Egypt. Cancer Epidemiology, 33 (3-4): pp. 176-81, 2009.

21- FELIX A.S., SOLIMAN A.S., KHALED H., ZAGHLOUL M.S., BANERJEE M., EL-BARADIE M., EL-KALAWY M., ABD-ELSAYED A.A., ISMAIL K., HABLAS A. and SEIFELDIN I.A.: The changing patterns of bladder cancer in Egypt over the past 26 years. Cancer Causes \& Control, 19 (4): pp. 421-9, 2008.

22- FREEDMAN N.D., SILVERMAN D.T., HOLLENBECK A.R., SCHATZKIN A. and ABNET C.C.: Association between smoking and risk of bladder cancer among men and women. Jama, 306 (7): pp. 737-45, 2011.

23- GANDOMANI H.S., TARAZOJ A.A., SIRI F.H., KARIMI ROZVEH A., HOSSEINI S., BORUJENI N.N., MOHAMMADIAN-HAFSHEJANI A. and SALEHINIYA H.: Essentials of bladder cancer worldwide: Incidence, mortality rate and risk factors. Biomedical Research and Therapy, 4 (9): pp. 1638-55, 2017.

24- GRACHTCHOUK M., MO R., YU S., ZHANG X., SASAKI H., HUI C.C. and DLUGOSZ A.A.: Basal cell carcinomas in mice overexpressing Gli2 in skin. Nature genetics, 24 (3): p. 216, 2000.

25- GUPTA P., JAIN M., KAPOOR R., MURUGANANDHAM K., SRIVASTAVA A. and MANDHANI A.: Impact of age and gender on the clinicopathological characteristics of bladder cancer. Indian Journal of Urology: IJU: Journal of the Urological Society of India, 25 (2), p.207, 2009.

26- HE X., MARCHIONNI L., HANSEL D.E., YU W., SOOD A., YANG J., PARMIGIANI G., MATSUI W. and BERMAN D.M.: Differentiation of a highly tumorigenic basal cell compartment in urothelial carcinoma. Stem cells, 27 (7): pp. 1487-95, 2009.

27- IBRAHIM A.S., KHALED H.M., MIKHAIL N.N., BARAKA H. and KAMEL H.: Cancer incidence in Egypt: Results of the national population-based cancer registry program. Journal of Cancer Epidemiology, 2014, 2014.

28- IDE M., KATO T., OGATA K., MOCHIKI E., KUWANO H. and OYAMA T.: Keratin 17 expression correlates with tumor progression and poor prognosis in gastric adenocarcinoma. Annals of Surgical Oncology, 19 (11): pp. 3506-14, 2012.

29- JEMAL A., BRAY F., CENTER M.M., FERLAY J. WARD E. and FORMAN D.: Global cancer statistics. CA: A Cancer Journal for Clinicians, 61 (2): pp. 69-90, 2011.

30- KHALED H.M., ALY M.S. and MAGRATH I.T.: Loss of $\mathrm{Y}$ chromosome in bilharzial bladder cancer. Cancer genetics and cytogenetics, 117 (1): pp. 32-6, 2000.

31- KIEMENEY L.A., SULEM P., BESENBACHER S., VERMEULEN S.H., SIGURDSSON A., THORLEIFSSON G., GUDBJARTSSON D.F., STACEY S.N., GUDMUNDSSON J., ZANON C. and KOSTIC J.: A sequence variant at $4 p 16.3$ confers susceptibility to urinary bladder cancer. Nature Genetics, 42 (5): p. 415, 2010.

32- KIRILUK K.J., PRASAD S.M., PATEL A.R., STEINBERG G.D. and SMITH N.D.: March. Bladder cancer risk from occupational and environmental exposures. In Urologic Oncology: Seminars and Original Investigations, (Vol. 30, No. 2, pp. 199-211). Elsevier, 2012.

33- KOYUNCUER A.: Histopathological Evaluation of Urothelial Carcinomas in Transurethral Resection Urinary Bladder Tumor Specimens: Eight Years of Single Center Experience. Asian Pacific Journal of Cancer Prevention, 16 (7): pp. 2871-7, 2015.

34- KYRITSI F., LOFFREDO C.A., ZHENG Y.L., PHILIPS G. and AMR S.: Urinary Bladder Cancer in Egypt: Are There Gender Differences in Its Histopathological Presentation? Advances in Urology, 2018.

35- LETASIOVÁ S., MEDVE’OVÁ A., SOVCÍKOVÁ A., DU SINSKÁ M., VOLKOVOVÁ K., MOSOIU C. and BARTONOVÁ A.: Bladder cancer, a review of the environmental risk factors. Environmental Health, 11 (1): p. S11, 2012.

36- LIU Y., BUI M.M. and XU B.: Urothelial carcinoma with squamous differentiation is associated with high tumor stage and pelvic lymph-node metastasis. Cancer Control, 24 (1): pp. 78-82, 2017.

37- MAHDAVIFAR N., GHONCHEH M., PAKZAD R., MOMENIMOVAHED Z. and SALEHINIYA H.: Epidemiology, incidence and mortality of bladder cancer and their relationship with the development index in the world. Asian Pacific Journal of Cancer Prevention, 17 (1): pp. 381-6, 2016.

38- MOCKLER D., ESCOBAR-HOYOS L.F., AKALIN A., ROMEISER J., SHROYER A.L. and SHROYER K.R.: Keratin 17 is a prognostic biomarker in endocervical glandular neoplasia. American Journal of Clinical Pathology, 148 (3): pp. 264-73, 2017. 
39- MOHAMED A.H., RAMADAN M.E., HELMY O.M. and MOHAMED S.S.: Immunohistochemical Expression of CD 10 and HER-2/NEU in Urothelial Carcinoma versus Chronic Cystitis in Zagazig University Hospitals (Retrospective Study). Zagazig University Medical Journal, 23 (2), 2017.

40- MOLL R., DIVO M. and LANGBEIN L.: The human keratins: Biology and pathology. Histochemistry and Cell Biology, 129 (6): p. 705, 2008.

41- MOSTAFA M.H., SHEWEITA S.A. and O'CONNOR P.J.: Relationship between schistosomiasis and bladder cancer. Clinical Microbiology Reviews, 12 (1): pp. $97-$ 111, 1999.

42- REGENBOGEN E., MO M., ROMEISER J., SHROYER A.L.W., ESCOBAR HOYOS L.F., BURKE S. and SHROYER K.R.: Elevated expression of keratin 17 in oropharyngeal squamous cell carcinoma is associated with decreased survival. Head \& Neck, 40 (8): pp. 178898, 2018.

43- SHAMSEDDINE A., SALEH A., CHARAFEDDINE M., SEOUD M., MUKHERJI D., TEMRAZ S. and SIBAI A.M.: Cancer trends in Lebanon: A review of incidence rates for the period of 2003-2008 and projections until 2018. Population Health Metrics, 12 (1): p. 4, 2014.

44- SOMJI S., CAO L., MEHUS A., ZHOU X.D., SENS M.A., DUNLEVY J.R., GARRETT S.H., ZHENG Y., LARSON J.L. and SENS D.A.: Comparison of expression patterns of keratin $6,7,16,17$, and 19 within multiple independent isolates of As+3-and Cd+2-induced bladder cancer. Cell Biology and Toxicology, 27 (6): p. 381, 2011.

45- THIKE A.A., CHEOK P.Y., JARA-LAZARO A.R., TAN B., TAN P. and TAN P.H.: Triple-negative breast cancer: Clinicopathological characteristics and relationship with basal-like breast cancer. Modern Pathology, 23 (1), p. $123,2010$.

46- VOLANIS D., KADIYSKA T., GALANIS A., DELAKAS D., LOGOTHETI S. and ZOUMPOURLIS V.: Environmental factors and genetic susceptibility promote urinary bladder cancer. Toxicology Letters, 193 (2): pp. 131-7, 2010.

47- WANG Y.F., LANG H.Y., YUAN J., WANG J., WANG R., ZHANG X.H., ZHANG J., ZHAO T., LI Y.R., LIU J.Y. and ZENG L.H.: Overexpression of keratin 17 is associated with poor prognosis in epithelial ovarian cancer. Tumor Biology, 34 (3): pp. 1685-9, 2013.

48- WONG M.C., FUNG F.D., LEUNG C., CHEUNG W.W., GOGGINS W.B. and NG C.F.: The global epidemiology of bladder cancer: A join point regression analysis of its incidence and mortality trends and projection. Scientific reports, 8 (1): p. 1129, 2018.

49- ZHENG Y.L., AMR S., DOA'A A.S., DASH C., EZZAT S., MIKHAIL N.N., GOUDA I., LOAY I., HIFNAWY T.,ABDEL-HAMID M. and KHALED H.: Urinary bladder cancer risk factors in Egypt: A multicenter case-control study. Cancer Epidemiology and Prevention Biomarkers, 21 (3): pp. 537-46, 2012.

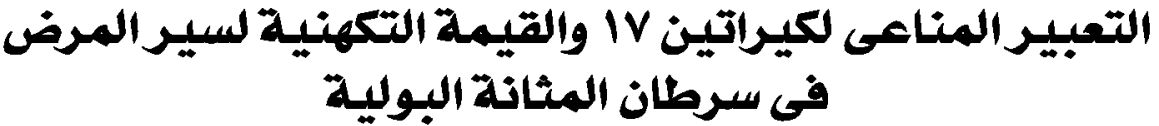

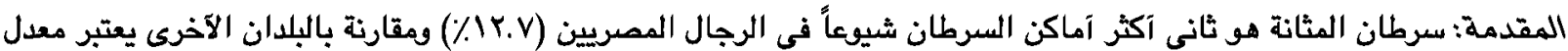

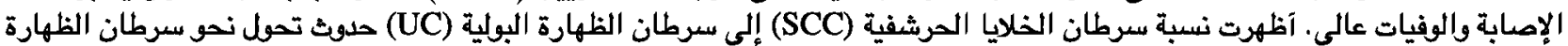

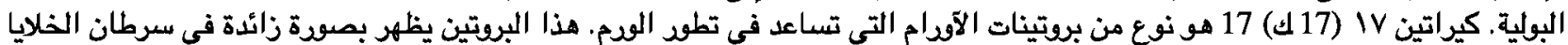
الحرشفية وسرطان الثىى الثُالثى السلبية وآودام آخرى.

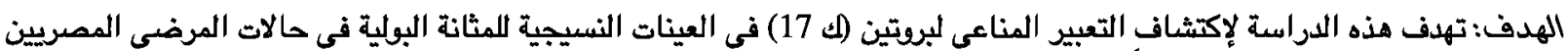

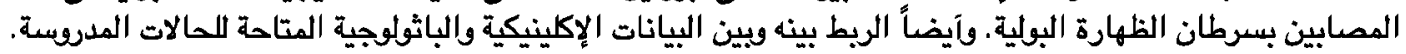

المرضى وطرق الدراسة: آجريت هذه الدراسة على .7 حالة من مرضى سرطان الظهارة البولية المصريين. تم عمل قطاعات من مكعبات

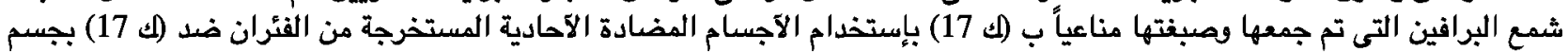

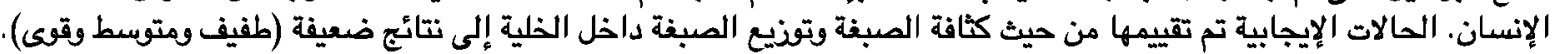

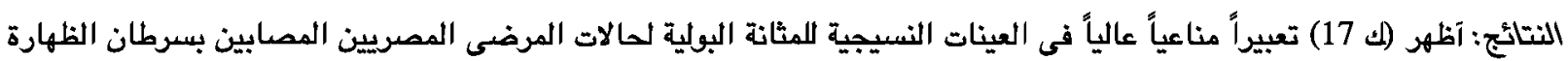

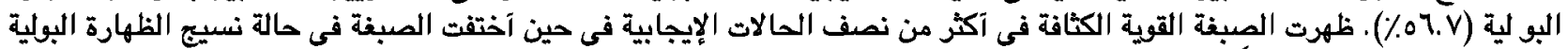

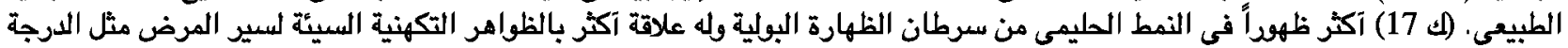

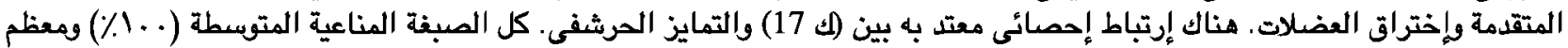

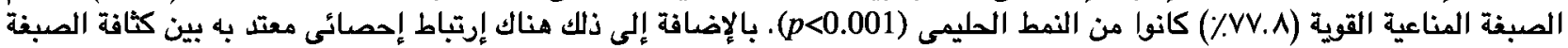

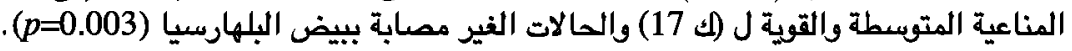

الختام: هذه الدراسة تستدعى الإنتباه تجاه التعبير المناعى العالى ل (ك 17) فى سرطان الظهارة البولية خاصة النمط الحليمى والدرجة العارية

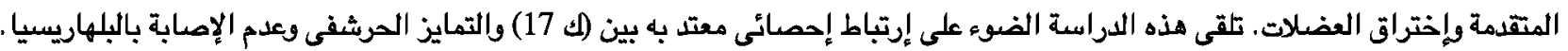

